\title{
Ontogenetic migration of a female scalloped hammerhead shark Sphyrna lewini in the Gulf of California
}

\author{
E Mauricio Hoyos-Padilla1,2, James T Ketchum ${ }^{1,5}$, A Peter Klimley ${ }^{3}$ and Felipe Galván-Magaña ${ }^{4^{*}}$
}

\begin{abstract}
Background: Little information exists on the vertical and horizontal movements of juvenile scalloped hammerhead sharks (Sphyrna lewini). Measurements of the sizes of juveniles caught in nets close to shore and those swimming in schools at seamounts and islands in the southwestern Gulf of California, Mexico indicate that at least part of the population undergoes a migration during their life cycle at a length of approximately $115 \mathrm{~cm}$ total length (TL) from coastal to offshore waters. Three juvenile hammerhead sharks were outfitted with archival tags in Mazatlan and La Paz Bay (LPB), Mexico during February 2006 and January 2007, respectively.

Results: A single juvenile female measuring $95 \mathrm{~cm}$ TL tagged in LPB was recaptured. It traveled a distance of approximately 3,350 km during a 10.5-month period from $L P B$ northward to the central Gulf of California and returning to $L P B, 11.7 \mathrm{~km}$ north of the location it was tagged. During this migration, the hammerhead increasingly moved from shallow coastal waters to deeper waters to possibly maximize its foraging success. After moving offshore, the shark remained in shallow and warm waters of less than $30 \mathrm{~m}$ depth and as high as $32^{\circ} \mathrm{C}$ during the day, and made repeated dives to deeper and colder waters of $250 \mathrm{~m}$ depth and $11^{\circ} \mathrm{C}$, at night.

Conclusions: Our study documents a female scalloped hammerhead shark changing life history phases from a nursery-inhabiting juvenile inshore to a migratory sub-adult offshore. We also infer that this shark swam within a school of conspecifics at an offshore island or seamount during the day, and migrated away at night, diving to greater depths to feed on mesopelagic prey. We show that this female shark carried out her complete biological cycle in both coastal and offshore areas of the central and southwestern Gulf of California, suggesting maximization of foraging opportunities and continued growth. In this study, we provide evidence for the first time of an ontogenetic migration of a juvenile scalloped hammerhead shark in the Gulf of California, which could be of great significance for the regional management and conservation of sharks in the Gulf of California.
\end{abstract}

Keywords: Ontogeny, Movements, Archival tag, Hammerhead shark, Gulf of California

\section{Background}

In fisheries analyses, it has been reported that hammerhead sharks are experiencing drastic population declines in excess of $90 \%$ in several parts of their global range because of overexploitation [1]. Three species of hammerheads (Sphyrna lewini, S. media, and S. mokarran) were recently added to Appendix II of the Convention on International Trade in Endangered Species [2], which will

\footnotetext{
*Correspondence: galvan.felipe@gmail.com

${ }^{4}$ Departamento de Biología Marina y Pesquerías, Centro Interdisciplinario de Ciencias Marinas (CICIMAR), Ap. Postal 592, La Paz, B.C.S. 23000, Mexico Full list of author information is available at the end of the article
}

better regulate trade in hammerhead shark products. However, their inclusion is unlikely to wholly solve the issue of overexploitation or bycatch [3]. Six of the eight hammerheads known to date are distributed in the Mexican Pacific (S. corona, S. lewini, S. media, S. mokarran, S. tiburo, and S. zygaena), and these species, with the exception of S. corona, were abundant in the Gulf of California in the 1960s [4]. Recently, it appears that S. media, S. mokarran, and S. tiburo might have been extirpated from the Gulf of California, and the most frequent hammerheads in fishery-dependent and fishery-independent surveys are S. zygaena and S. lewini [4]. The scalloped hammerhead S. lewini is a circumglobal 
species that inhabits warm temperate and tropical seas. In the eastern Pacific, this species occurs from southern California to Ecuador [5]. Scalloped hammerhead sharks are known to school in great numbers at small islands and seamounts in the eastern tropical Pacific and are very susceptible to fisheries while moving into the open sea [6]. Though considered abundant in the Gulf of California in the 1980s, hammerhead shark populations have declined considerably or have become extirpated from the Gulf in recent years [4].

Understanding the temporal and spatial scales at which sharks move is of paramount importance to ecologists and conservationists since it gives us a better understanding of habitat use and key sites occupied by these species [7]. Many ecologically and commercially important marine animals have life histories in which juvenile stages use different habitats than adults [8]. Such ontogenetic shifts in movements, habitat, and depth ranges use are prevalent among fishes, including sharks [9]. Moreover, many species exhibit ontogenetic changes in feeding patterns that reflect changing roles within ecological communities, and this trait has been documented in several species of sharks [10-12]. Based on stomach content analyses, Klimley [13] argued that as scalloped hammerhead sharks mature, they migrate into deeper water. Although males remain in shallow water until they reach a size of $160 \mathrm{~cm} \mathrm{TL}$, female hammerheads begin to migrate offshore sooner, at a length of $115 \mathrm{~cm} \mathrm{TL}$, to inhabit offshore seamounts and islands [13]. Current understanding of the ontogenic migration of the scalloped hammerhead shark in the Gulf of California is based largely on the incidental take of juveniles and stomach content analyses from a relatively small number of individuals $[14,15]$. Furthermore, the seasonal change in abundance of scalloped hammerhead shark landings by artisanal fishermen [16] and seasonal presence of large schools at volcanic islands and seamounts [14,17], suggest that this species migrates away from this region but returns to the same locations annually. However, actual migratory pathways have yet to be identified for this species. Using an archival tag to track a single female scalloped hammerhead shark for a period of 10.5 months, we were able to describe what we believe to be an ontogenetic migration of the individual as it migrated from shallow coastal areas to deep offshore waters. In addition, we provide evidence that open ocean migration of female juvenile hammerheads may be fitness-related.

\section{Results}

One female juvenile hammerhead shark tagged in LPB was recaptured in this same location. The other two juveniles tagged in Mazatlan were never recaptured. The juvenile female recaptured in LPB travelled approximately 3,350 km during a 10.5-month period. After her release on 26 January 2007, the shark remained close to shore near the tagging site in LPB for 20 days (Figure 1). By 8 February, the juvenile had moved $11.6 \mathrm{~km}$ northward along the coast of the bay remaining in less than $50 \mathrm{~m}$ of water. The next position was recorded on 18 April, located $18,450 \mathrm{~km}$ northeast of San Pedro Nolasco Island in waters of a similar depth $(50 \mathrm{~m})$, indicating that the shark was still occupying a coastal habitat but on the mainland coast of the Gulf of California, near Guaymas, Mexico. However, the shark travelled at a depth averaging more than $100 \mathrm{~m}$ on 17 March (Figure 2A), which is evidence of a transit across the Gulf of California from the peninsular coast to the mainland. On 21 April, the shark again crossed the Gulf and was swimming in coastal waters at depths of less than $50 \mathrm{~m}$, north of Bahia Concepcion. From May to August the shark remained in waters less than $50 \mathrm{~m}$ deep (Figure 2A), mostly close to the shore, although two positions (May 21 and June 7) were recorded in offshore waters (see Figure 1).

From 27 January to 15 August the shark performed shallow dives most of the time (see Figure 2A), but after 16 August she started to make deeper dives as indicated by the greater depths occupied per day (see Figure 2B). A record of the diving behavior of the female over a single day during the coastal period of residence indicates that the shark remained close to the surface in waters no deeper than $50 \mathrm{~m}$ (Figure 3A). Upon moving offshore, her average depth recorded over a $24 \mathrm{~h}$ period was greater, and the shark reached a depth exceeding $240 \mathrm{~m}$ on one occasion. This is apparent on a record of a single day that shows swimming depths above $50 \mathrm{~m}$ during daytime (06:00 to 18:00) and from 120 to $250 \mathrm{~m}$ during nighttime (19:00 to 05:00; Figure 3B). This seasonal shift in depth is also apparent when comparing depths over all months, particularly from August to December (Figure 4). The last position recorded was in 23 December 2007 when the juvenile was recaptured near San Jose Island (north of LPB).

There was a significant relationship between maximum depth of the hammerhead and ambient temperature during all months (January to December; $X^{2}$ test, $P<0.001$ ), and between actual depth and ambient temperature across the life of the tag (322 days; $\chi^{2}$ test, $P<0.001$ ). We also found a significant diel difference (day vs. night) in depth during all months (Mann-Whitney test, $P<0.001$ ), and a significant difference between most months (Dunn's method, $P<0.05$, see Figure 4$)$.

\section{Discussion}

We describe here the horizontal and vertical movements of a female juvenile scalloped hammerhead at the time it is believed to have made an ontogenetic movement from shallow coastal waters, which they inhabit for the first 3 years of their life, to offshore locations. Prior studies suggest that adult hammerheads display a diel pattern in relation to their use of seamounts $[17,18]$, forming schools around seamounts during the day and dispersing to forage 


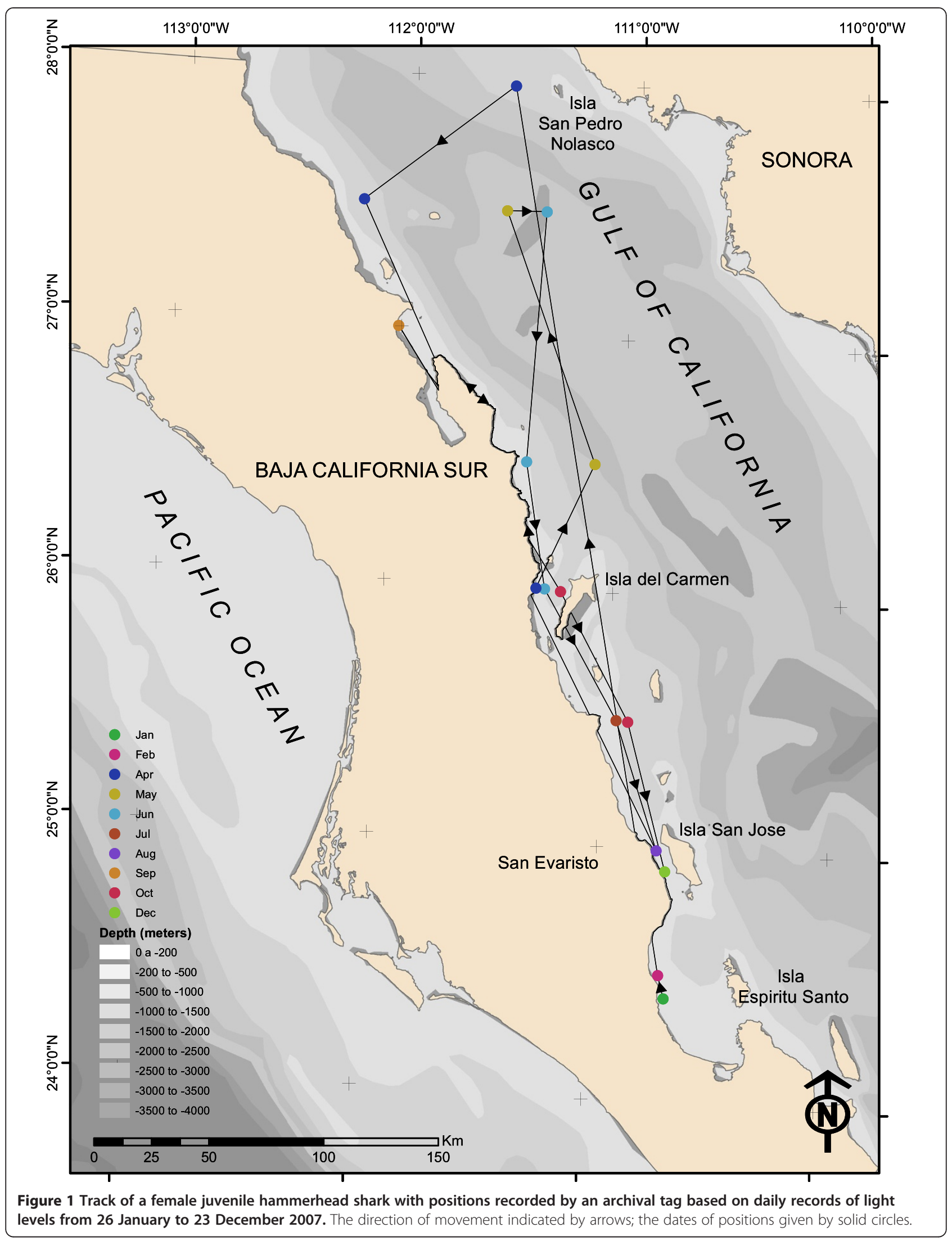



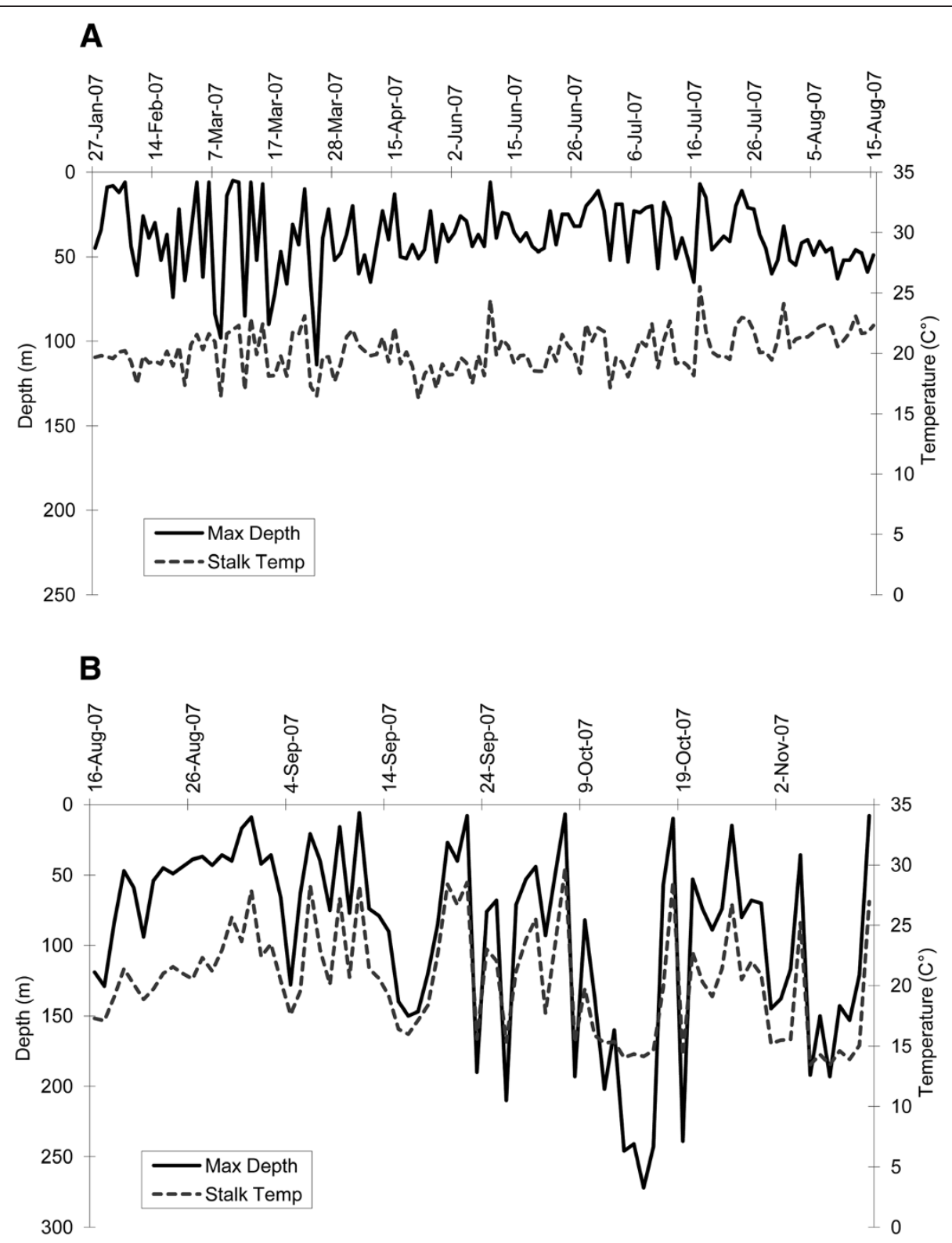

Figure 2 Maximum excursions of female scalloped hammerhead (solid line) and temperatures (dashed line) at the diving depths.

(A) Inshore movements from 27 January to 15 August 2007, (B) offshore movements from 16 August to 11 November 2007.

in open water at night. This diel pattern has also been observed around Malpelo [19] and Galapagos [20] islands. It is assumed that they make offshore migrations into the pelagic environment at night to feed on pelagic fish and squid $[13,21]$. Little was known about the movements of juvenile hammerhead sharks in the pelagic realm, nevertheless, here we document such horizontal and vertical movements.

The female juvenile shark performed the shallowest dives from 23 May to 2 July and the deepest dives from 4 September to 7 November, indicative also of an ontogenetic migration offshore. This migration likely occurred after the first days of September when the dive oscillations became much greater with the shark making regular dives between 150 to $250 \mathrm{~m}$ (see Figure 2B). The shallowest dives were performed during the transitional months from May to July (spring to summer), when the depth of the thermocline is usually shallow. According to Ketchum et al. [20], hammerhead sharks perform frequent vertical excursions above the thermocline during offshore movements and, in general, were observed to prefer temperatures of $23^{\circ} \mathrm{C}$ to $26^{\circ} \mathrm{C}$, which are found above the thermocline. The deepest dives of the female hammerhead in this study were performed from late summer to late fall (from September to December), when the thermocline is deeper (see Figures 2B and 4). 


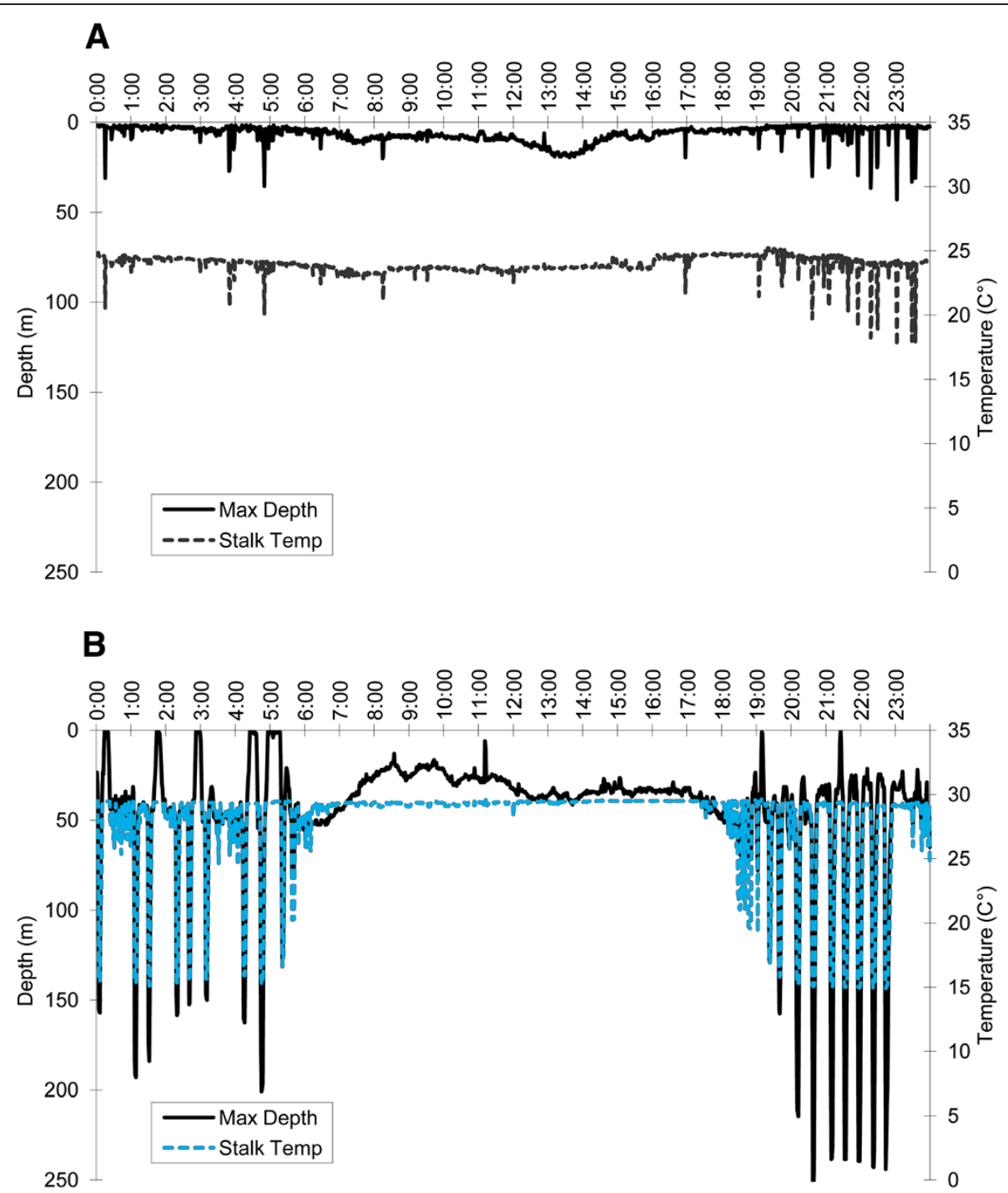

Figure 3 Vertical movements of female scalloped hammerhead shark over a 24 hcycle during (A) a coastal period of residence on 6 June 2007 and (B) during offshore residence on $\mathbf{8}$ October 2007.

An alternative factor possibly influencing the vertical movements of the juvenile shark could be the stable oxygen minimum layer. In the southern Gulf of California, this layer is well pronounced between 250 and $800 \mathrm{~m}$ deep. In the case of our tagged juvenile shark, vertical movements ranged from the surface to $272 \mathrm{~m}$ in a 10-month period. In contrast, the vertical movements of an adult scalloped hammerhead shark tracked by Jorgensen et al. [22] ranged from the surface to a depth of at least $980 \mathrm{~m}$. Hence, adults can inhabit a highly expanded, vertical niche in the open ocean, tolerating large fluctuations in temperature and extremely low levels of dissolved oxygen.

One possible explanation for the offshore ontogenetic migration is that females move into open waters due to social factors. The social factor hypothesis states that sexual segregation may be maintained by aggression of one sex towards the other [13]. Therefore, sub-adult females could also leave inshore areas to avoid aggressive behavior of males [23]. Nevertheless, there is little information on the behavior of juvenile hammerheads in inshore areas of the Gulf of California that could support this hypothesis.

Another explanation for the offshore migration may be environmental. There was a cold episode during the second half of 2007 [24]. However, the relationship between these climatic processes and trophic responses is often complex and may be delayed in response to the primary climate signal change. These effects may manifest in predator population distributions, movements, densities, phenology, behavior, and community interactions [25]. Although the behavior of the juvenile hammerhead could be influenced by these phenomena, the ontogenetic 


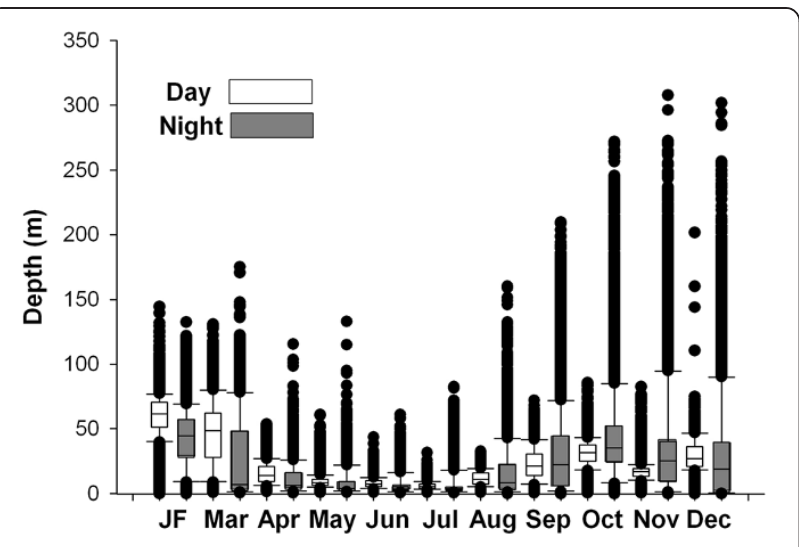

Figure 4 Seasonal and diel vertical movements of female scalloped hammerhead shark over the life of the tag (January to December 2007). Black circles denote outliers. JF = January-February.

migration of a juvenile hammerhead coincides more with the offshore movements of females at an early age related to diet and growth differential as shown by previous studies in the Gulf of California [13].

An additional explanation is fitness-related. Capture data indicate that female scalloped hammerhead sharks migrate offshore at a smaller size than males. Females in the size range of 74 to $125 \mathrm{~cm}$ were captured at a median depth of $50 \mathrm{~m}$, whereas males with same size range were caught at a median depth of $25 \mathrm{~m}$ [13]. When the female shark in this study was tagged she had a size of $95 \mathrm{~cm} \mathrm{TL}$ and remained in shallow waters above $50 \mathrm{~m}$ depth from January to August (Figure 2A). Ten months later, when the female was recaptured, she had a size of $123 \mathrm{~cm}$ TL. This size corresponds to a 4-year-old female [26]. Between the ages of 3 to 4 years, females grow at a more rapid rate than males in the Atlantic off the coast of North Carolina [27]. Similarly, an average female at an age of 4 years has a TL of $119 \mathrm{~cm}, 6 \mathrm{~cm}$ larger than a male of the same age, even larger than a male of 5 years, in the Gulf of California [13]. Thus, an offshore movement of females results in a growth differential [13]. It is possible, then, that the juvenile females are trying to get offshore as quickly as possible to jockey for position, assert dominance in the schools, and establish social rank. In a comparative study of teleost and elasmobranch schooling behavior, Klimley [14] observed that scalloped hammerhead shark schools are comprised predominantly of females with larger individuals aggressively vying for central positions within the school. Schools of hammerheads at offshore seamounts and islands in the Gulf of California studied during late 1970's and early 1980's were composed of juveniles as well as larger individuals of both sexes [14]. This was evident from a frequency distribution of individual sharks measured using stereo-photography, where only females existed in the 113, 128 , and $143 \mathrm{~cm}$ TL size classes [28].
Moreover, this offshore movement of female scalloped hammerhead sharks at an earlier age than males results in different diets between them. As might be expected from their early offshore movement, according to Klimley [13], females less than $160 \mathrm{~cm}$ TL fed on a higher percentage of pelagic prey than did males of similar sizes. Mesopelagic prey formed $27.5 \%$ of the female total Index of Relative Importance (IRI) and epipelagic prey formed only $5.5 \%$ of the female IRI, and only $18.1 \%$ and $3.6 \%$ of the male total IRI, respectively. Furthermore, the diet of the females consisted of only $15.1 \%$ benthic prey in comparison to $40.9 \%$ benthic prey of the IRI of male sharks. Scalloped hammerhead shark pups have high metabolic rates and frequently feed on prey of low caloric value while in nursery grounds. Thus, they require higher ration levels to fulfill their energetic needs. Those sharks that do not become successful in learning how to catch prey quickly may starve as the result of their high energetic requirements [29], which would partially explain the early fledging of this juvenile female to offshore waters for richer food.

The recorded depths of the female hammerhead during a single day in October 2007, showed swimming depths above $50 \mathrm{~m}$ during the day and 120 to $250 \mathrm{~m}$ during the night (see Figure 3B), possibly indicating a diel change of lifestyle, from refuging in large schools at seamounts during the day to venturing into deep water to feed at nighttime [30]. And, vertical movements of the hammerhead during all months represent a seasonal shift of lifestyle after August 2007, from shallow to deeper waters (see Figure 4). The mass of the stomachs of female sharks larger than $100 \mathrm{~cm} \mathrm{TL}$ and smaller than $160 \mathrm{~cm}$ TL exceed those of males of the same size [13], likely representing greater foraging success for females as they make diel migrations into the deep waters surrounding the seamounts to feed on pelagic fishes and squid [31]. A possible adaptive advantage from this early offshore migration of females is increased growth despite greater exposure to risk of predation. Increased body size would not only provide more body cavity space for the female's ova or embryos, but also more muscle and a larger liver for energy storage, later to be allocated to reproduction [13]. Supporting the assertion that greater growth increases reproductive success in females and not males is continued growth of the former upon reaching maturity and absence of such growth in the latter [13]. Hence, smaller female sharks trade-off the risks of an open ocean migration at an early age for the opportunity to get big quick and increase their reproductive potential.

The presence of neonates, gravid females, and small juveniles of scalloped hammerhead sharks in LPB and in the southeastern coast of the Gulf of California, indicates that these areas are used as a nursery for this species [16,17]. In addition, the presence of male and female adult hammerheads during the summer in seamounts in the southwestern Gulf of California [16], in the mid-riff islands, and 
southeastern Gulf [17], suggests that these places are important as mating aggregation sites for the scalloped hammerhead shark.

\section{Conclusions}

We report here for the first time evidence of an ontogenetic migration of a juvenile scalloped hammerhead shark in the Gulf of California. Our study documents a female scalloped hammerhead shark changing life history phases from a nursery-inhabiting juvenile inshore to a migratory subadult offshore. We also infer that this shark swam within a school of conspecifics at an offshore island or seamount during the day, and migrated away at night, diving to greater depths to feed on mesopelagic prey. We show that this female shark carried out her complete biological cycle in both coastal and offshore areas of the central and southwestern Gulf of California, suggesting maximization of foraging opportunities and continued growth. Thus, by growing faster female hammerheads may be increasing their reproductive potential.

Increased human fishing pressure has reduced the size of the population of scalloped hammerhead populations to a negligible size in the Gulf of California, with the species becoming extremely rare in the Mexican Pacific. Current management measures set forth by the Mexican government, such as the prohibition of shark-finning and commercial fisheries from large vessels within 50 nautical miles from the coast (NOM-029 [2]) and seasonal closures on shark fisheries since 2012 [2], have resulted in some protection for some species of sharks. However, our observations suggest that hammerheads may be particularly susceptible to fisheries due to their use of both coastal and offshore waters during early life stages. Considering life history, vulnerability to fisheries, and global endangered status of scalloped hammerheads, current management measures for sharks in Mexico may be insufficient for the conservation of this species. Thus, our findings on the movements and behavior of a small juvenile S. lewini may be conducive to more effective conservation actions for this threatened species in the Gulf of California and elsewhere. On the other hand, there is a growing awareness that Marine Reserves and other forms of time-area closures have the potential to play a more important role in shark conservation, especially for the protection of site-attached species and vulnerable critical habitats. In the case of scalloped hammerheads, coastal nursery grounds and offshore refuging areas at seamounts are critical habitats where marine reserves should be sited. Finally, the low sample size in this study yields limitations of the overall results of the study, thus considerable additional research is needed in order to determine critical habitats of hammerheads in the Gulf of California. Although, we believe this work provides evidence of an important stage in the life cycle of scalloped hammerhead sharks, and this is of great significance for the regional management and conservation of threatened sharks in the Gulf of California.

\section{Methods}

To determine the movement patterns of juvenile hammerheads, three individuals in the size range of 89 to $95 \mathrm{~cm}$ TL, were captured in the Gulf of California with the assistance of local artisanal fishermen. A male and female juvenile, 89 and $91 \mathrm{~cm}$ TL, respectively, were tagged in Mazatlan during February 2006 and a female, $95 \mathrm{~cm}$ TL, in LPB in January 2007. Hand-lines with barbless curved hooks were used with squid as bait to capture the juvenile sharks. A nylon-head, plastic dart tag was inserted into the musculature just below the first dorsal fin across the body midline for external identification. An incision about $2 \mathrm{~cm}$ long was made with a sterile surgical scalpel blade in the abdominal wall $5 \mathrm{~cm}$ in front of the base of the pelvic fins. A MK-9 archival tag (Wildlife Computers, Redmond, WA, USA) was inserted through the incision into the peritoneal cavity, with the stalk and light sensor protruding outside. The incision was closed with a surgical stapler and the shark was released into the water. The archival tag was set to record depth, sea temperature, and light levels every $30 \mathrm{~s}$. Because these were archival tags with no transmission to a passing satellite, they had to be recovered to obtain the recorded information. Hence, we included a reward notice on the tag to be able to recover it from local fishers. Only the shark tagged in LPB, a female captured at a size of $95 \mathrm{~cm} \mathrm{TL}$, was re-captured by an artisanal fisherman $11.7 \mathrm{~km}$ north of the same location where it was tagged after 10.5 months at liberty. Data were downloaded from the tag, and initial exploratory data analyses were conducted, using software provided by the tag manufacturer (WC-DAP). Daily latitude and longitude were estimated by geolocation, and latitude was corrected using SST recorded by the tag and matched to a remotely-sensed SST along the corresponding longitudinal meridian using the methodology of Teo et al. [32]. In spite of this correction, a number of spurious positions were eliminated because they were either unattainable using the fastest rate of movement of a juvenile hammerhead or appeared on land. Then, each set of corrected positions was integrated into a Geographic Information System (ArcGIS 10.2) and plotted in a map with a bathymetric scale of the Gulf of California. In double-tagging experiments, the root mean square errors of the light level longitude estimates were $0.89^{\circ}$ and $0.55^{\circ}$; while for SST latitude estimates, the root mean square errors were $1.47^{\circ}$ and $1.16^{\circ}$ for salmon sharks and blue sharks, respectively [32]. Hence, the positions of the hammerhead sharks should be interpreted in the context of the sharks being either close to the eastern coast of the Peninsula of Baja California, or offshore in the Gulf of California. All measurements of depth and 
temperature were included in our analyses and examined for diurnal patterns, habitat preference, and additional behaviors. We examined the relationship between depth and temperature across the life of the tag with a Chi-square test. We also examined diel (day vs. night) and seasonal differences in depth over the life of the tag using MannWhitney and Kruskal-Wallis tests. All statistical analyses were performed with SigmaStat 3.5 (Systat Software Inc., Chicago, IL, USA).

\section{Abbreviations}

LPB: La Paz Bay.

\section{Competing interests}

The authors declare that they have no competing interests.

\section{Authors' contributions}

MHP participated in the design of the experiment, conducted all fieldwork, drafted the manuscript and created the figures. JTK performed the data analyses and helped to draft the manuscript. APK conceived the study together with FGM, participated in the data analyses, and assisted to draft the manuscript. FGM designed the experiment and helped to draft the manuscript. All authors read and approved the final manuscript.

\section{Acknowledgements}

This work was made possible by a Collaborative Research Grant, entitled 'Determination of migratory corridor of hammerhead sharks in Gulf of California' from UC MEXUS to the University of California, Davis, and the Centro Interdisciplinario de Ciencias Marinas (CICIMAR), La Paz. Support was provided by local fishermen in La Paz and Mazatlan. Fellowships for FGM were provided by the Instituto Politécnico Nacional (COFAA, EDI).

\section{Author details}

${ }^{1}$ Pelagios-Kakunjá, Sinaloa 1540, La Paz, B.C.S. 23070, Mexico. ${ }^{2}$ Fins Attached, 19675 Still Glen Drive, Colorado Springs, CO 80908, USA. ${ }^{3}$ Department of Wildlife, Fish, and Conservation Biology, University of California, Davis, One Shields Avenue, Davis, CA 95616, USA. ${ }^{4}$ Departamento de Biología Marina y Pesquerías, Centro Interdisciplinario de Ciencias Marinas (CICIMAR), Ap. Postal 592, La Paz, B.C.S. 23000, Mexico. ${ }^{5}$ Centro de Investigaciones Biológicas del Noroeste, La Paz, B.C.S. 23096, Mexico.

Received: 5 July 2014 Accepted: 16 October 2014

Published: 26 November 2014

\section{References}

1. Baum JK, Myers RA, Kehler DG, Worm B, Harley SJ, Doherty PA: Collapse and conservation of shark populations in the Northwest Atlantic. Science 2003, 299:389-392

2. CITES: Convention on International Trade in Endangered Species of Wild Fauna and Flora 2012. Proposals for amendment of appendices I and II (CoP16 Prop. 43). [http://www.cites.org/eng/cop/16/prop/E-CoP16-Prop-43.pdf]

3. Gallagher AJ, Hammerschlag N, Shiffman DS, Giery ST: Evolved for extinction: the cost and conservation implications of specialization in hammerhead sharks. Bioscience 2014, 64(7):619-624. doi:10.1093/biosci/biu071.

4. Pérez-Jiménez JC: Historical records reveal potential extirpation of four hammerhead sharks (Sphyrna spp.) in Mexican Pacific waters. Rev Fish Biol Fisher 2014, 24:671-683.

5. Compagno LJV: Carcharhiniformes. FAO Fish Synop. In FAO Species Catalogue, Sharks of the World. An Annotated and Illustrated Catalogue of Shark Species Known to Date. Volume 4. Part 2. Edited by Kautenberger M, De Angelis N. Rome: FAO; 1984:251-655.

6. Ketchum JT, Hearn A, Klimley AP, Peñaherrera C, Espinoza E, Bessudo S, Soler G, Arauz R: Inter-island movements of scalloped hammerhead sharks (Sphyrna lewini) and seasonal connectivity in a marine protected area of the Eastern Tropical Pacific. Mar Biol 2014, 161:939-951.

7. Schneider DC: Quantitative Ecology: Spatial and Temporal Scaling. San Diego, CA: Academic; 1994.
8. Adams AJ, Dahlgren CP, Kellison GT, Kendall MS, Layman CA, Ley JA, Nagelkerken I, Serafy JE: Nursery function of tropical back-reef systems. Mar Ecol Prog Ser 2006, 318:287-301.

9. Grubbs RD: Ontogenetic Shifts in Movements and Habitat Use. Chapter 7. In Sharks and Their Relatives II: Biodiversity, Adaptive Physiology, and Conservation. Edited by Carrier JF, Musick JA, Heithaus MR. Boca Raton, FL: CRC Press; 2010:319-350.

10. Tricas TC, McCosker JE: Predatory behavior of the white shark (Carcharodon carcharias), with notes on its biology. Proc Calif Acad Sci 1984, 43:221-238.

11. Lowe CG, Wetherbee BM, Crow GL, Tester AL: Ontogenetic dietary shifts and feeding behavior of the tiger shark, Galeocerdo cuvier, in Hawaiian waters. Environ Biol Fish 1996, 47:203-211.

12. Yamaguchi A, Taniuchi T: Food variations and ontogenetic dietary shift of the star spotted dogfish Mustelus manazo at five locations in Japan and Taiwan. Fisheries Sci 2000, 66:1039-1048.

13. Klimley AP: The determinants of sexual segregation in the scalloped hammerhead shark, Sphyrna lewini. Environ Biol Fish 1987, 18:27-40.

14. Klimley AP: Schooling in the large predator, Sphyrna lewini, a species with low risk of predation: a non-egalitarian state. Ethology 1985, 70:297-319.

15. Torres-Rojas YE, Hernández-Herrera A, Galván-Magaña F, Alatorre-Ramírez VG: Stomach content analysis of juvenile scalloped hammerhead shark Sphyrna lewini captured off the coast of Mazatlán, Mexico. Aquat Ecol 2010, 44:301-308.

16. Klimley AP, Nelson DR: Schooling of the scalloped hammerhead Sphyrna lewini in the Gulf of California. Fish Bull 1981, 79:256-260.

17. Torres-Huerta AM, Villavicencio-Garayzar C, Corro Espinoza D: Reproductive biology of the scalloped hammerhead shark Sphyrna lewini Griffith \& Smith (Sphyrnidae) in the Gulf of California. Hidrobiologica 2008, 18:227-238

18. Klimley AP, Butler SB, Nelson DR, Stull T: Diel movements of scalloped hammerhead sharks, Sphyrna lewini Griffith and Smith, to and from a seamount in the Gulf of California. J Fish Biol 1988, 33:751-761.

19. Bessudo S, Soler GA, Klimley AP, Ketchum JT, Hearn A, Arauz R: Residency of the scalloped hammerhead shark (Sphyrna lewini) at Malpelo Island and evidence of migration to other islands in the Eastern Tropical Pacific. Environ Biol Fish 2011, 91:165-176.

20. Ketchum JT, Hearn A, Klimley AP, Espinoza E, Peñaherrera C, Largier JL: Seasonal changes in movements and habitat preferences of the scalloped hammerhead shark (Sphyrna lewini) while refuging near an oceanic island. Mar Biol 2014, 161:755-767.

21. Galván MF, Nienhuis HJ, Klimley AP: Seasonal abundance and feeding habits of sharks of the lower Gulf of California, Mexico. Calif Fish Game 1989, 75:74-84.

22. Jorgensen SJ, Klimley AP, Muhlia-Melo AF: Scalloped hammerhead shark Sphyrna lewini, utilizes deep-water, hypoxic zone in the Gulf of California. J Fish Biol 2009, 74:1682-1687.

23. Sims DW: Differences in Habitat Selection and Reproductive Strategies of Male and Female Sharks. In Sexual Segregation in Vertebrates: Ecology of the two Sexes. Edited by Ruckstuhl KE, Neuhaus P. Cambridge: Cambridge University Press; 2005:127-147.

24. NOAA: 2014. http://www.cpc.ncep.noaa.gov/products/analysis_monitoring/ ensostuff/ensoyears.shtml.

25. Trathan PN, Forcada J, Murphy EJ: Environmental forcing and Southern Ocean marine predator populations: effects of climate change and variability. Philosp Trans R Soc B 2007, 362:2351-2365.

26. Anislado-Tolentino V, Cabello MG, Linares FA, Mendoza CR: Age and growth of the scalloped hammerhead shark, Sphyrna lewini (Griffith \& Smith, 1834) from the Southern coast of Sinaloa, México Edad y crecimiento del tiburón martillo, Sphyrna lewini (Griffith \& Smith, 1834) de la costa sur de Sinaloa, México. Hidrobiológica 2008, 18:31-40.

27. Schwartz FJ: Shark ageing methods and age estimation of scalloped hammerhead, Sphyrna Lewini and Dusky, Carcharhinus Obscurus, sharks based on vertebral ring counts. In Proceedings of the International Workshop on Age Determination of Oceanic Pelagic Fishes: Tunas, Billfishes, and Sharks, NOAA Tech. Rep. NMFS, Volume 8. Edited by Prince ED, Pulos LM. Washington, DC: Dept. of Commerce; 1983:167-174.

28. Klimley AP, Brown ST: Stereophotography for the field biologist: measurement of lengths and three-dimensional positions of free-swimming sharks. Mar Biol 1983, 74:175-185. 
29. Lowe CG: Bioenergetics of free-ranging juvenile scalloped hammerhead sharks (Sphyrna lewini) in Kāne'ohe Bay, Ö'ahu. HI Jour Exp Mar Biol Ecol 2002, 278:141-156.

30. Klimley AP, Nelson DR: Diel movement patterns of the scalloped hammerhead shark (Sphyrna lewini) in relation to El Bajo Espiritu Santo: a refuging central-position social system. Behav Ecol Sociobiol 1984, 15:45-54.

31. Klimley AP: Highly directional swimming by scalloped hammerhead sharks, Sphyrna lewini, and subsurface irradiance, temperature, bathymetry, and geomagnetic field. Mar Biol 1993, 117:1-22.

32. Teo SLH, Boustany A, Blackwell S, Walli A, Weng KC, Block BA: Validation of geolocation estimates based on light level and sea surface temperature from electronic tags. Mar Ecol Prog Ser 2004, 283:81-98.

doi:10.1186/2050-3385-2-17

Cite this article as: Hoyos-Padilla et al: Ontogenetic migration of a female scalloped hammerhead shark Sphyrna lewini in the Gulf of California. Animal Biotelemetry 2014 2:17.

\section{Submit your next manuscript to BioMed Central and take full advantage of:}

- Convenient online submission

- Thorough peer review

- No space constraints or color figure charges

- Immediate publication on acceptance

- Inclusion in PubMed, CAS, Scopus and Google Scholar

- Research which is freely available for redistribution 